\title{
Effect of Organic and Inorganic Nutrients on Yield of Rajmash (Phaseolus Vulgaris L.) in Dry Temperate Zone of Himachal Pradesh
}

\author{
Rajesh Singh , Y. P. Dubey* \\ Department of Seed Science \& Technology, College of Agriculture, CSK Himachal Pradesh Krishi Vishvavidyalaya, India
}

Copyright (C) 2015 Horizon Research Publishing All rights reserved.

\begin{abstract}
Spiti valley is endowed with mild summers and cool winters. The valley remains snow bound from mid November to March. Intense sun, high wind velocity, low humidity, scanty rainfall and high transpiration rate are the other features of climate of Spiti valley. Use of bio-fertilizers is gaining momentum by the farmers of Himachal Pradesh in organic farming. The use of phosphate solubilizing bacteria as inoculants simultaneously increases $\mathrm{P}$ uptake by the plant and crop yield. Strains from the genera Pseudomonas, Bacillus and Rhizobium are among the most powerful phosphate solubilizers. Rajmash (Phaseolus vulgaris L.) is a potential cash crop grown in dry temperate zone of Himachal Pradesh. Being a leguminous crop its phosphorus requirement is higher. Among the various components of production technology, fertilizers are the kingpin for improving the productivity of rajmash. The scarcity of organic material in the dry temperate zone indicates that the productivity depends on integrated nutrient management. Thus the present study with two inoculations (Rhizobium and Rhizobium+Phosphate solublising bacteria), four nitrogen levels $(0,20,40,60 \mathrm{~kg} / \mathrm{ha})$ and two phosphorus levels (75\% and $100 \%$ recommended) was undertaken. Rajmash yield increased by inoculation. Grain yield increased with increasing $\mathrm{N}$ levels. Substitution of $25 \% \mathrm{P}$ did not increase the yield of rajmash significantly. Similarly straw yield of rajmash differ significantly by inoculation in both the years. Recommended level of P@60 kg/ha proved better than 75\% of recommended P. After analyzing soil samples at harvest it was revealed that inoculation with Rhizobium+PSB gave more availability of $\mathrm{N}(222.8 \mathrm{~kg} / \mathrm{ha}), \mathrm{P}(26.6 \mathrm{~kg} / \mathrm{ha})$ and $\mathrm{K}$ $(8.96 \mathrm{~kg} / \mathrm{ha})$ in comparison to Rhizobium alone.
\end{abstract}

Keywords Rajmash, Inoculation, Rhizobium, Phosphate Solubilizing Bacteria

\section{Introduction}

Rajmash (Phaseolus vulgaris L.) is the important crop grown in dry temperate region of Himachal Pradesh. It is the cash crop of the area and has great demand in plains and fetches premium price because of its quality and better taste. Use of integrated nutrients in rajmash increased its productivity on one hand and improves the soil status on the other.

The continuous use of inorganic fertilizers has shown the gradual decline in fertilizer use efficiency when applied without organic sources. Phosphate solubilizer enhanced the efficiency of nitrogen fixing bio-fertilizers and improves soil properties.

Therefore partial substitution of mineral nutrients using organic sources has been well envisaged (Chatopadhyay and Chatterjee,2004). Organic sources and bio-fertilizers are the most essential components of integrated nutrient management. Therefore the present investigation was undertaken to economize the dose of fertilizers along with bio-fertilizers.

\section{Materials and Methods}

A field experiment was conducted in factorial randomized block design during summer seasons of 2008 and 2009 at Research Sub-Station, Lari $(3300 \mathrm{msl})$ of CSK Himachal Pradesh Krishi Vishvavidyalaya, Palampur. Cold dessert winds are peculiar feature of the area which lowers the mercury down to $-25^{\circ} \mathrm{C}$ to $-30^{\circ} \mathrm{C}$ during winters. Average rainfall ranges from $150-200 \mathrm{~mm}$. The soil of the experimental field was silty loam in texture with loose soil strata. The soils in general are low in organic matter and high in potash. The recommended levels of $\mathrm{N}, \mathrm{P}$ and $\mathrm{K}$ for the crop are 20, 60 and $30 \mathrm{~kg} / \mathrm{ha}$ respectively. The treatment combinations comprised of two inoculations \{Rhizobium and Rhizobium+Phosphate solublising bacteria(Bacillus megaterium $\}$, four $\mathrm{N}$ levels $(0,20,40,60 \mathrm{~kg} / \mathrm{ha})$ and two Phosphorus levels (75\% and 100\% recommended). The N, P and $\mathrm{K}$ were applied through urea, single super phosphate and muriate of potash respectively. Rajmash cultivar Jwala was used as test crop. Seed and straw yields were recorded at harvest. Impact of inoculation was studied in soil after the harvesting in second year rajmash crop for nitrogen, phosphorus and potassium availability by standard methods. 
Table 1. Effect of inoculation, nitrogen and phosphorus on Grain yield of Rajmash

\begin{tabular}{ccc}
\hline Treatments & \multicolumn{2}{c}{ Rajmash Grain Yield $(\mathrm{q} / \mathrm{ha})$} \\
& Summer 08 & Summer 09 \\
Rhizobium & Inoculation & 18.2 \\
Rhizobium $+\mathrm{PSB}$ & 20.3 & 21.3 \\
$\mathrm{CD}(\mathrm{P}=0.05)$ & 25.9 & $\mathrm{NS}$ \\
& 0.9 & \\
$\mathrm{~N}_{0}$ & Nitrogen levels & 14.8 \\
$\mathrm{~N}_{20}$ & 20.3 & 16.4 \\
$\mathrm{~N}_{40}$ & 22.6 & 23.2 \\
$\mathrm{~N}_{60}$ & 23.2 & 23.5 \\
$\mathrm{CD}(\mathrm{P}=0.05)$ & 25.7 & 1.68 \\
& 1.20 & 18.6 \\
$75 \%$ of rec. $\mathrm{P}_{2} \mathrm{O}_{5}$ & Phosphorous levels & 18.9 \\
$100 \%$ rec. $\mathrm{P}_{2} \mathrm{O}_{5}$ & 23.0 & $\mathrm{NS}$ \\
$\mathrm{CD}(\mathrm{P}=0.05)$ & 23.1 & \\
\hline
\end{tabular}

Table 2. Effect of inoculation, nitrogen and phosphorus on straw yield of Rajmash

\begin{tabular}{ccc}
\hline Treatments & \multicolumn{2}{c}{ Rajmash Straw Yield (q/ha) } \\
& Summer 08 & Summer 09 \\
Inoculation & 8.2 \\
Rhizobium & 9.8 & 10.4 \\
Rhizobium+PSB & 12.5 & 1.34 \\
$\mathrm{CD}(\mathrm{P}=0.05)$ & 0.6 & \\
& Nitrogen levels & 7.9 \\
$\mathrm{~N} 0$ & 10.3 & 8.4 \\
$\mathrm{~N} 20$ & 10.8 & 9.1 \\
$\mathrm{~N} 40$ & 11.0 & 9.8 \\
$\mathrm{~N} 60$ & 12.5 & $\mathrm{NS}$ \\
$\mathrm{CD}(\mathrm{P}=0.05)$ & 0.8 & \\
& Phosphorous levels & 9.6 \\
$75 \%$ of rec. $\mathrm{P} 2 \mathrm{O} 5$ & 11.0 & 11.2 \\
$100 \%$ rec. $\mathrm{P} 2 \mathrm{O} 5$ & 11.3 & 0.47 \\
$\mathrm{CD}(\mathrm{P}=0.05)$ & $\mathrm{NS}$ & \\
& &
\end{tabular}

\section{Results and Discussions}

It is evident from Table 1 that rajmash yield increased by inoculation. Inoculation with Rhizobium $+P S B$ gave more yield than inoculation with Rhizobium alone in both the years. Increase in yield was significant in first year and numerically more in second year. The increase in seed yield of rajmash owing to balanced fertilizers application was also observed by Kumar et. al. (2005).Effects of nitrogen levels were significant in both the years. Grain yield of rajmash increased with increasing nitrogen levels. Substitution of 25 percent phosphorus did not reduce yield significantly. Recommended level of phosphorus @ 60 kg/ha (100 percent) did not prove better than 75 percent of recommended phosphorus in increasing the yield of rajmash. These results further authenticated the findings of Rana et.al (2001).
Straw yield of rajmash differed significantly by inoculation in both the years (Table 2). Inoculation with Rhizobium+PSB gave significantly more yield than inoculation with Rhizobium alone. Straw yield increased with increase in N levels from 20 to $60 \mathrm{~kg} / \mathrm{ha}$. Substitution of 25 percent phosphorus did not affected the straw yield significantly in the first year but in the second year 100 percent recommended level of phosphorus proved better than 75 percent of recommended phosphorus.

A perusal of data presented in Table 3 revealed that inoculation with Rhizobium and Rhizobium+PSB showed a significant effect on nitrogen, phosphorus and potassium status after harvesting the second year rajmash crop. Nutrient statuses in all the treatments have increased from its initial status. Initial status of nitrogen, phosphorus and potassium was determined at start of experiments. 
Table 3. Effect of inoculation, nitrogen and phosphorus levels on available nitrogen, phosphorus and potassium after harvesting of rajmash

\begin{tabular}{|c|c|c|c|}
\hline \multirow[t]{2}{*}{ Treatment } & \multicolumn{3}{|c|}{ Available nutrients $(\mathrm{kg} / \mathrm{ha})$} \\
\hline & Nitrogen & $\begin{array}{l}\text { Phosphorus } \\
\text { Inoculation }\end{array}$ & Potassium \\
\hline Rhizobium & 208.6 & 18.4 & 156.4 \\
\hline Rhizobium+PSB & 222.8 & 26.6 & 170.6 \\
\hline $\mathrm{CD}(\mathrm{P}=0.05)$ & 7.4 & 3.84 & 8.96 \\
\hline \multicolumn{4}{|c|}{ Nitrogen levels } \\
\hline $\mathrm{N}_{0}$ & 196.4 & 18.5 & 149.4 \\
\hline $\mathrm{N}_{20}$ & 203.8 & 22.6 & 160.2 \\
\hline $\mathrm{N}_{40}$ & 212.5 & 24.5 & 165.8 \\
\hline $\mathrm{N}_{60}$ & 218.6 & 25.8 & 176.4 \\
\hline $\mathrm{CD}(\mathrm{P}=0.05)$ & 10.4 & 4.73 & 13.4 \\
\hline \multicolumn{4}{|c|}{ Phosphorous levels } \\
\hline $75 \%$ of rec. $\mathrm{P}_{2} \mathrm{O}_{5}$ & 198.6 & 20.8 & 162.8 \\
\hline $100 \%$ rec. ${ }_{2} \mathrm{O}_{5}$ & 218.6 & 23.4 & 178.3 \\
\hline $\mathrm{CD}(\mathrm{P}=0.05)$ & 9.6 & NS & 10.47 \\
\hline $\begin{array}{c}\text { Initial Status of } \\
\text { NP\&K }\end{array}$ & 214 & 18 & 195 \\
\hline
\end{tabular}

Inoculation with Rhizobium+PSB gave more available nitrogen, phosphorus and potassium than inoculation with Rhizobium alone. Increasing doses of nitrogen increased available nutrient status. The maximum nitrogen, phosphorus and potassium were recorded in $60 \mathrm{~kg} \mathrm{~N}$ ha- 1 applied treatment and the minimum was recorded in $20 \mathrm{~kg} \mathrm{~N}$ ha-1applied treatment. Recommended phosphorus level gave significantly more nitrogen and potassium than 75 percent of recommended phosphorus applications. But the available status of phosphorus did not differ significantly. Recommended phosphorus (100 percent) gave numerically more available phosphorus than 75 percent of recommended phosphorus applied treatment.

\section{Conclusions}

Conjoint use of Rhizobium $+P S B$ gave more grain and straw yield of rajmash than inoculation with Rhzobium alone. Substitution of 25 percent of recommended phosphorus with phosphate solubilizing microorganisms proved significantly at par grain yield of rajmash on one hand and improves significantly the nitrogen and potassium status of soil after harvest of crop.

\section{REFERENCES}

[1] Chattopadhay GN and Chatterjee RP 2004. Vermicomposting as a tool for organic waste management in agriculture. In: Proceedings of National Symposium on Resource Conservation and agricultural productivity, held at PAU, Ludhiana, Nov.22-25.

[2] Kumar P, Verma TS, Bindra AD and Rana MC 2005. Response of rajmash (Phaseolus vulgaris L.) to integrated nutrient management in dry temperate region of H.P. Himachal Journal of Agricultural Research 31:15-19.

[3] Rana RS, Rana SS, Chahota RK, Sharma GD and Mankotia B 2001. Influence of row spacing and fertility levels on the productivity and economics of rajmash (Phaseolus vulgaris L.) in dry temperate region of H.P. Himachal Journal of Agricultural Research 27:11-18. 